\title{
Student Satisfaction and Service Quality: Any Differences in Demographic Factors?
}

\author{
Azleen Ilias \\ School of International Business and Finance Labuan \\ Universiti Malaysia Sabah, Labuan International Campus, 87000, F.T Labuan, Malaysia \\ Tel: 60-8-746-0517 E-mail: neelza80@yahoo.co.uk \\ Hishamuddin Fitri Abu Hasan \\ Research and Planning Department, Public Service Department of Malaysia \\ Federal Government Administrative Centre, 62510, F.T Putrajaya, Malaysia \\ Tel: 60-12-500-3429Ｅ-mail: hishamfitri@jpa.gov.my \\ Rahida Abd Rahman \& Mohd Rushdan bin Yasoa' \\ School of International Business and Finance Labuan \\ Universiti Malaysia Sabah, Labuan International Campus, 87000, F.T Labuan, Malaysia \\ Tel: 60-8-746-0517Ｅ-mail: neelza80@yahoo.co.uk
}

\begin{abstract}
Previously, very less research done to test demographic factors that contribute towards satisfaction and service quality. This study attempts to examine the differences of selected demographic factors (gender, races and semester of studies) on the students' satisfaction and service quality. Furthermore, this study is also to examine any relationship between age and students' satisfaction and service quality. This study was conducted using a set of questionnaire to 200 Bachelor Degree students from two private higher education institutions. The study will provide results from empirical test of these differences and relationships. The empirical results of this study can provide any differences, which related to students' satisfaction on service quality.
\end{abstract}

Keywords: Service Quality, Private higher education institutions

\section{Introduction}

\subsection{Introduction}

In today's competitive academic environment where students have many options available to them, factors that enable educational institutions to attract and retain students should be seriously studied. Higher education institutions, which want to gain competitive edge in the future, may need to begin searching for effective and creative ways to attract, retain and foster stronger relationships with students. As a private organization, it has to depend on the interaction and mechanism of the market. As a result, competition to woo as many students as possible or so-called "potential customer" may become more and more intense. To make the matter harder, as a private institution, it does not have the "privilege" to receive any subsidies or financial assistances from the government (Teo, 2001).

An expectation that cannot be fulfilled on the institutions is the key factors for students' withdrawal (Alridge and Rowley, 2001). According to the study by Kanji, Abdul Malek and Wallace (1999) do give some insights on the real situation of the Higher Education Institutions in Malaysia. Most institutions do give a great deal of importance to meeting customers' expectations which is similar to business organization, but they still lack customer awareness among the staff, and it has become a common drawback for many institutions.

This bring us to an understanding that students will have more opportunity to support their continued enrollment into higher educational institutions and on how well the educational programs and services met students' expectations for services. In this competitive market, satisfaction with services may make the difference (Parasuraman, Zeithaml and Berry 1996). This study attempts to explore the aspects of service quality and the level of satisfaction among the students of private higher education institutions. 


\subsection{Problem Statement}

Particularly in Malaysia, National Accreditation Body (LAN) once had to reject accreditation applications of 40 programs by private higher learning institutions due to the weaknesses in core course structures. Among factors that contributed toward the problems were the lecturers' lack of skills to handle the task and failure to attain the required curriculum standard set up by LAN (Mohd Feroz Abu Bakar, 2004).

The government for example has for long not compromising on the quality of education offered and hope to see that the private higher education will provide a quality education toward the students ("We won't compromise", 2001). This of course is in-synchronization with the current trend in education industry. Former Education Minister Tan Sri Musa Mohamad, has once made a statement regarding the weakness in the private HEI. According to him, he is aware there is a change of attitude among the present students nowadays as they are getting bolder in exercising their rights to demand for quality. One of his remarks on this issue is, "Don't be surprised if a student takes one of you to court for not teaching properly.” (Rajah and Nadarajah, 2000).

In fact this is true as an issue on professionalism of an administration and the academic staffs of the private higher institution has been raised in one of the newspaper by the frustrated student due to his/her college misguided concern on issues like college reputation by "forcing" the students to involve in charitable activities that in the end overlook the bigger issue which is their academic performance ("Unprofessional College", 2004). This of course shows that students nowadays are indeed do not wait and see for the changes to be made but will put an effort to find an effective channels to voice their grievances if the management do not demonstrate that they care towards the complaints.

The intention here is obvious and well made but the problem is, comparing to the public higher education learning, it seems the perceptions of the people toward the private higher education tend to be biased in term of quality. It seems that the majority of students and parents especially Bumiputera place their hopes on public higher education institutions. If the students fail to be offered a place there, the perception is that he or she will have a bleak future. This is something that should not happen, as even the Prime Minister himself does not want these institutions to be the "last resort options" or a poorer alternative to public universities (Ling, 2003).

\subsection{Research Question}

RQ1: What are the differences of selected demographic factors on the students' satisfaction?

RQ2: What are the differences of selected demographic factors on the service quality?

RQ3: What is the relationship between age and students' satisfaction?

RQ4: What is the relationship between age and service quality?

\subsection{Research Objectives}

Generally, the purpose of this study is to determine the difference in service quality and student satisfaction in two private higher institutions. Several factors in service quality that will be discussed and analyzed are Tangibility, Assurance, Reliability, Responsiveness and Empathy.

The purpose of this research:

- To examine the differences of selected demographic factors (gender, races and semester of studies) on the students' satisfaction

- To examine the differences of selected demographic factors (gender, races and semester of studies) on the service quality.

- To examine any relationship between age and students' satisfaction

- To examine any relationship between age and service quality

\subsection{Significance of the Study}

Enhancing service quality has been demonstrated across numerous industries. The quality of service that can be applied to universities, especially to private universities, differentiates them from their public counterparts. Private HEI while attempting to compete at academic levels with other HEIs should offer an added advantage to champion quality services to their students. Notably, it can even be assumed to be an important road to the competitive excellence for the service oriented organization as by neglecting these aspects of quality services will put such organization at a competitive disadvantage compared to its counterparts because most of its revenues are enrollment related thus affecting its financial health (Zammuto et al., 1996). This study is important because it is going to measure the level of service quality and the level of satisfaction among the students as have been stressed by Iacobucci, Ostrom and Grayson (1995), "Presumably, if quality programs were initiated based on marketing research- that is, the changes were market driven and customer oriented- the quality improvements should lead to customer satisfaction" (p. 296). The result from the study can be used to give valuable information on the elements and the dimensions, which have been given a priority by students in assessing the quality of services and satisfaction. In addition to that, this study is going to provide the conclusions and 
some recommendations, which are hoped that it's going to provide useful information to the private higher education institutions.

\section{Literature}

\subsection{Service Quality in Higher Education}

It is interesting to identify here about the applicability of SERVQUAL to education sector, meaning that there is a suitability of applying it in higher education. Numerous studies have adapted this measurement in HEI, such as SQ in business schools (Rigotti and Pitt, 1992) and higher educational institutions (Cuthbert, 1996; Soutar and McNeil, 1996; Saaditul, Samsinar and Wong, 2000).

In the study by Cuthbert (1996) it has been found that among the dimension in SQ, the score for tangibility (3.34) is the highest, followed by assurance (3.21), reliable (3.11), responsive (3.04) and empathy (2.58). However he added that this does not represent tangibility as a major contributor towards satisfaction of the students as he believes it is the service encounter which is the determinant factor. O'Neill and Palmer (2004) also hold the exact same idea that, although tangibility is ranked as the best in term of overall performance score, but it has been ranked as the least importance by the students compared to process and empathy. Study by Perisau and McDaniel (1997) is best described as, assurance and reliability has been identified as the most important suggesting that students are most concern with the knowledge, courtesy and ability to inspire trust and confidence which is part of the assurance dimension.

Nevertheless, there are studies that have a different opinion on the importance of tangibility dimension in service quality. Smith and Ennew (2001) outlined an interesting aspect in his research toward the SQ in higher education. He highlighted that there is difficult aspect in the choice of satisfaction perception of customer between the affective indignation and the technical functionality. For example, the particular facility consumed by the students could be judged according to how reliable they are (technical functionality) or according to their ages, appearances, courtesy and empathy (affective). The perfect reliable facility, which is not up to date, but are capable of carrying out the task, may still be negatively rated if the users expect the university to provide up to date facility. He also showed that there were specific supportive items known as peripheral aspect and the university facilities, which students consume such as cafeterias and residential accommodation that will directly and indirectly have a significant impact on the evaluation of the university. Based on the study by Umbach and Porter (2002), it also appears that the size or a number of faculties within a department in HEI is important in explaining student satisfaction.

LeBlanc and Nguyen (1997) for example stressed on the reputation as a factor, which is tied closely to management's capacity to foster an organizational climate directed at serving the needs of its customers and to the image of the HEI. It is also process-related in that, it involves an ability to inspire trust and confidence and provide personal attention to students in a professional and caring manner. In term of importance, the study has shown that perceived value is derived mainly from price/quality, a factor that is closely tied to the business school's capacity to offer sufficient services to students and convince them that they are receiving quality services in exchange for what they give by means of their tuition fees.

While Ford, Joseph and Joseph (1999) go a little bit more specific on the services in their study about service quality by comparing the importance score of service quality in higher education for the New Zealand student sample and the United States sample. They found that for the New Zealand sample, academic reputation has been ranked as the first followed by career opportunities, programme issues, cost/time, physical aspects, location and others while for the USA sample, it was found that the first rank is academic reputation, cost/time, programme issues, others, physical aspects and choice influences.

Earlier researches on service quality in higher education also often emphasized academic more than administration, concentrating on effective course delivery mechanisms and the quality of courses and teaching (Atheeyaman, 1997; Cheng and Tam, 1997; Soutar and McNeil, 1996; Griemel-Fuhrmann and Geyer, 2003). However there are also an attempt to look upon the administrative side of higher institution like the study by Kamal and Ramzi (2002), which attempt to measure student perception of registration and academic advising across different faculties and other administrative services to assure positive quality service that compliments the academic.

\subsection{Service Quality and Students'Satisfaction}

Service Quality is commonly noted as a critical prerequisite for establishing and sustaining satisfying relationship with valued customers. In this way, the association between service quality and customer satisfaction has emerged as a topic of significant and strategic concern (Cronin and Taylor, 1992). In general, perceived service quality is an antecedent to satisfaction (Spreng and Mckoy, 1996). Thus, a proper understanding of the antecedents and determinants of customer satisfaction can be seen as to have an extraordinarily high monetary value for service organization in a competitive environment (Lassar, Manolis and Winsor, 2000).

Bigne, Moliner and Sanchez (2003) found that the overall service quality have a significant relationship with 
satisfaction at $\mathrm{R}=0.66$. Ham and Hayduk (2003) have confirmed that, even in the higher educational settings, there is a positive correlation between perception of service quality and student satisfaction, and analyzing upon the relationship based on each of the dimension of service quality, reliability $(\mathrm{R}=0.547$; sig. $=0.000)$ has the strongest relationship followed by responsiveness and empathy $(\mathrm{R}=0.5431$; sig. $=0.000)$, assurance $(\mathrm{R}=0.492$; sig. $=0.000)$ and tangibility $(\mathrm{R}=0.423$; sig. $=0.000)$.

Elliot and Shin (2002) found that the highly significant variables in the model that appear to directly impact overall customer satisfaction with university performance are: (1) excellence of instruction in major $(0.0522 ; p<0.0002)$, (2) able to get desired classes $(0.0935 ; \mathrm{p}<0.0000)$, (3) knowledgeable advisor $(0.0517 ; \mathrm{p}<0.0000)$, (4) knowledgeable faculty $(0.0406 ; \mathrm{p}<0.0094)$, (5) overall quality of instruction $(0.0510 ; \mathrm{p}<0.0000)$, (6) tuition paid is a worthwhile investment $(0.0749 ; \mathrm{p}<0.0000)$, (7) approachable advisor $(9.0631 ; \mathrm{p}<0.0000)$, (8) safe and secure campus $(0.0646$; $\mathrm{p}<0.0000)$, (9) clear and reasonable requirements for major $(0.0539 ; \mathrm{p}<0.0000),(10)$ availability of advisor $(0.0537$; $\mathrm{p}<0.0000)$, (11) adequate computer labs $(0.0631 ; \mathrm{p}<0.0000)$, (12) fair and unbiased faculty $(0.0443 ; \mathrm{p}<0.0004)$, and (13) access to information $(-0.367 ; \quad \mathrm{p}<0.0021)$.

\subsection{Demographic Factors}

\subsubsection{Gender}

a) Gender in Satisfaction

Most of the study found that there is no significant difference between gender and satisfaction (Corts, Lounsbury, Saudargas and Tatum, 2000; Rosenthal, Folse, Alleman, Bourdreaux, Soper and Bergen, 2000; Carey et al. 2002).

Yet there are some studies that suggest otherwise finding that women have a lower satisfaction compare to men (Renzi, Allen, Sarmento and McMillin, 1993; Umbach and Porter, 2002). Perry, Sekelsy and Skarsten, (2003) also share the same finding except that the women seems to be more satisfied than male.

\section{b) Gender in Service Quality}

The study by Soutar and McNeil (1996) found that there is a significant relationship between gender and satisfaction with service quality as it would seem that males are more satisfied than females. This however is different based on the study by Joseph and Joseph (1998) that showed there is no significant difference between male and females.

In addition to that, Ham and Hayduk (2003) also supported this finding when from their research; it is found that gender has no significant relationship with perceived service quality even though the findings do show that males are more satisfied compared to females.

\subsubsection{Race/Ethnicity}

\section{a) Race/Ethnicity in Satisfaction}

Terenzini, Rendon, Upcraft, Millar, Allison, Gregg, and Jalomo (1996) explains that those who are minorities tend to focus on the academic aspects rather than social compared to non minority which are more concern on social aspects like meeting friends, developing friendship. As a result, the minority students tend to be more critical to the satisfaction on academic scopes compared to non-minority.

This is similar to the finding of Mather (2000) when measuring an overall satisfaction in the context of academic experience and social experience showed that non minority students score a higher level of satisfaction on the academic experience compared to the minority students.

Eimers (2001) may well support both of the findings above when he found that there is a significant difference between ethnicity and satisfaction on campus climate (minority $(\mathrm{m})=3.38$, non minority $(\mathrm{nm})=3.57$ ) and overall assessment $(\mathrm{m}=3.32 ; \mathrm{nm}=3.50)$ of higher institution with non-minority scores higher mean but Elrod and Remirez (2002) and Perry et al (2003) disagree with it when their finding shows that there is no significant difference between ethnicity and satisfaction.

\section{b) Race/Ethnicity in Service Quality}

Carey et al. (2002) in a study based on 3 different ethnicity to measure its differences with satisfaction level based on three scales which is responsibility to the diverse population, concern to the individual rights and student centeredness, reported that there is a significant difference when taking into account on the responsibility of the university towards the diverse population which surprisingly that the Caucasian students scored a lower satisfaction level compared to the other minority students.

\subsubsection{Semester of Studies}

\section{a) Semester of Studies in Satisfaction}

Corts et al. (2000) in his study on this demographic factor show that there is no significant differences between a junior and a senior students thus implying that their experience in the higher institution do not change their perception on 
satisfaction.

b) Semester of studies in Service Quality

Hill (1995) found that there is stability on the students' expectations over time suggesting that there were probably formed prior to arrival at university compared to students perceive quality as there is a reduction in quality experienced indicating that it is less stable.

To prove it further, the mean score for the students based on the semester of studies in the study by Oldfield and Baron (2000) showed that the score for the final year students were lower than those of the first year thus suggesting that as the students become more experienced in the higher educational settings, students tend to be more critical in their perception on the service quality.

Study by O'Neill (2003) has a better way of explaining through the use of longitudinal study to determine time factor on the perception of the service quality. This study that used the original instrument of SERVQUAL on the sample of 657 indicates that student's rate their perceptions of a phenomenon differently at the time of consumption compare to their rating subsequently.

Conversely, Hill (1995) showed that the time factor have an influence over the expectation by raising it which in the end affect the perceptions of the previous service. However, the study by Ham and Hayduk (2003) may tell a different story as it only has a significant relationship with the reliability dimension while others do not have a significant relationship.

\subsubsection{Age}

\section{a) Age in Satisfaction}

Age factor is also found to have no significant difference to the level of satisfaction (Carey, et al., 2002) thus suggesting that age factor cannot be related with the perception of satisfaction.

b) Age in Service Quality

Based on the study by Ham and Hayduk (2003) it is found that age have no significant relationship with service quality in higher educational settings for the students from Southern Wesleyan University (SWU) and Western Michigan University (WMU).

\subsection{Hypotheses of the Study}

Ho1: There is no significant difference between male and female in their satisfaction.

Ho2: There is no significant difference between male and female in the service quality

Ho3: The satisfaction of the students is same irrespective to the races.

Ho4: The satisfaction of the students is the same irrespective to the semester of studies.

Ho5: Service quality in higher education is the same irrespective to the races.

Ho6: Service quality in higher education is the same irrespective to the semester of studies

Ho7: There is no significant relationship between age and overall student satisfaction.

Ho8: There is no significant relationship between age and service quality in higher education

\section{Methodology}

\subsection{Research Framework}

This study was adopted from Parasuraman's SERVQUAL dimensions. The dependent variable in this study is overall student satisfaction that is measured by the overall satisfaction with the HEIs. The independent variable in this study is service quality in higher education that measures the level of satisfaction with service performance. The dimensions included in this variable are tangibility, assurance, responsiveness, reliability, and empathy. In addition to that, this study also tries to put together the demographic factors that will be used to measure the significance level with service quality and student satisfaction. Those factors include gender, age, races or ethnicity and semester of study.(see Figure 1)

\subsection{Sample}

The samples in this study were bachelor degree students studying at a Private HEIs. For that purpose, directory from http://www.studymalaysia.com/jps/directori/ senarai_ipts.shtml is use to identify the related private higher institutions that may serve as potential respondents. Respondent consists of Bachelor Degree students from Kuala Lumpur Infrastructure University College (KLiUC) and Kolej Universiti Teknologi dan Pengurusan Malaysia (KUTPM). We have distributed 230 questionnaires for every institution. Finally, 200 respondents completed and returned the questionnaires, which represents about $87 \%$ response rate.

\subsection{Instrumentation}

This study used questionnaire as a medium to obtain the data needed. There are three sections in the questionnaire, 
consisting of Section A: Demographic factor, Section B: Measurement of Service Quality in Higher Education and Section C: Measurement of Student Satisfaction. In this section A, four question covering from the subjects of gender, age, race or ethnicity, and their semester of study. Followed by section B: service quality in higher education and section C: student satisfaction. Instrument used in this research is adapted from Parasuraman et al. (1990) with some of the items used extracted from LeBlanc and Nguyen (1997) using the five dimensions in service quality (tangibility, assurance, reliability, responsiveness and empathy) using the Likert scale from 1 for not satisfied at all to 6 for very satisfied. In measuring student satisfaction, instrument for this variable was adapted from Atheeyaman (1997). In this variable, it has six items with Likert scale ranges from 1 for much worse than expected to 6 for much better than expected.

\subsection{Data Analysis Procedures}

The data analysis for this study conducted through 'Statistical Package for Social Science' software or SPSS version 12. The study also tested reliability of the instrument so that it enables to produce a robust and valid result.

\section{Findings}

\subsection{Profiles of the respondents}

The demographic information includes the following characteristic of participants: gender, age, semester of studies and ethnicity. The demographics information is represented in Table 1.1 based on frequency distributions and percentages.

From the 200 respondents in this study, 95 (47.5\%) are male and $105(52.5 \%)$ are females. The calculated mean age of the respondents is 23 years old with the majority of the students being 22 years old (33\%). Most of the respondents are in the fourth semester of their study (28\%), followed by fifth semester and above (27\%), second semester (20\%), third semester $(14.5 \%)$ and first semester (10.5\%). Majority of the respondents are Malay (72\%) followed by Chinese and Indian $(25 \%)$ and other ethnicity contributing about $3 \%$.

\subsection{T-Test Results}

The results of the T-test are shown in the Table 1.2 below. The differences in the satisfaction between male and female are 4.2561 and 4.0873 respectively with standard deviations of 0.99906 and 0.87556 (sig. $=0.204$ ). Thus, the result failed to reject Hol because there was no significant difference between male and female in their satisfaction.

The results of the T-test on the differences between male and female on service quality are also shown in the Table above with mean for male and female is 4.1491 and 4.0041 respectively and standard deviations at 0.72790 with significant level 0.138 . Thus, the result failed to reject Ho2 because there was no significant difference between men and women in service quality.

\subsection{ANOVA Results}

\section{ANOVA test for satisfaction}

The results of the ANOVA test shown in the Table 1.3 below do not indicate any significant differences in the level of satisfaction among the 4 groups of races $(\mathrm{F}=1.453$; sig. $=0.229)$. Therefore, the result failed to reject Ho3 because satisfaction was the same irrespective to the races.

It is the same for another ANOVA test on semester of study, which also indicates that there are no significant differences in the level of satisfaction $(\mathrm{F}=0.332$; sig. $=0.856)$. Therefore, the result failed to reject Ho4 because satisfaction was the same irrespective to the semester of studies.

ANOVA test for service quality

The result on the ANOVA test shown in Table 1.3 does not indicate any significant differences in the level of service quality among the four groups of races $(\mathrm{F}=0.972$; sig. $=0.407)$. Therefore, the result failed to reject $\mathrm{Ho} 5$ because service quality in higher education is the same irrespective to the races.

Another result on ANOVA test in Table 1.3 also does not indicate any significant differences in the level of service quality among the five groups $(\mathrm{F}=0.722 ; \mathrm{p}=0.578)$. Therefore, it failed to reject Ho6 because service quality in higher education is the same irrespective to the semester of studies.

\subsection{Correlation Results}

The outputs in Table 1.4 indicate the relationship result between age and satisfaction and service quality determinants. However, age as the result shows that there is no significant relationship for both satisfaction and service quality. Therefore, it has answered three hypotheses related to this analysis. The first fail to reject Ho7 as there is no significant relationship between age and satisfaction. The second also fail to reject $\mathrm{Ho} 8$ as there is no significant relationship between age and service quality. 


\section{Discussion and Conclusion}

In this final section of the study, discussions on the important findings of the study will be reviewed in terms of its significance and support by other researches. This study attempts to examine the differences of selected demographic factors (gender, races and semester of studies) on the students' satisfaction and service quality and secondly to examine any relationship between age and students' satisfaction and service quality.

\subsection{Discussion}

\subsubsection{Student satisfaction}

The results on demographic factors (gender, races and semester of studies) do not show any significance differences with satisfaction. Therefore, this study failed to reject Ho1, Ho3 and Ho4.

Ho1: there is no significant difference between male and female in their satisfaction.

This result is consistent with the finding from Corts et al. (2000), Rosenthal et al. (2000) and Carey et al. (2002), which found no significant difference, based on gender toward satisfaction. Therefore it rejects finding by Renzi et al. (1993) and Umbach and Porter (2002), which stated that male have higher satisfactions than female. Even though it did find male have a higher satisfaction compared to female still the result was not significant. In addition, this result contradicts with the finding by Perry, Sekelsy and Skarsten, (2003) that not only found there was a significant differences in satisfaction between male and female, but suggesting that women have a higher level of satisfaction compared to male.

Ho3: The satisfaction of the students is the same irrespective to the races.

Terenzini et al. (1996), Matter (2000) and Eimers (2001) try to give an indication that there is a difference on satisfaction if it is viewed on the basis of minority and non-minority students, suggesting that minorities tend to be more critical in their satisfaction evaluation but Elrod and Remirez (2002) and Perry et al (2003) tend to disagree with it because for them the results have suggest that there is no significant differences based on races. Thus, this study agreed with Elrod and Remirez (2002) and Perry et al (2003) as the result shows that satisfaction of the students would be the same irrespective to the races.

Ho4: The satisfaction of the students is the same irrespective to the semester of studies.

The finding has suggested that satisfaction is the same irrespective to the semester of studies. Although the students that gain more experience in the higher institution tend to be more critical in their evaluation, but the result does not find any significant differences in the level of satisfaction. This is consistent with the finding by Corts et al. (2000) that show the same finding when it was conducted on the junior and senior students in higher education.

Ho7: There is no significant relationship between age and student satisfaction.

Consistent with the finding by Carey, et al. (2002) this finding too does not find any significant relationship between age and satisfaction. This mean that age is not the determinant toward satisfaction irrespective of whether the students are mature, old or young.

\subsubsection{Service Quality}

The study on the demographic factors show the same finding like satisfaction as it demonstrates that demographic factors (gender, semester of studies, ethnicity) do not have any significant difference with service quality.

Ho2: there is no significant difference between male and female in their perceived service quality

The finding is consistent with the result by Joseph and Joseph (1998) Ham and Hayduk (2003), which also found the same thing. However this result contradict with the result depicted by Soutar and McNeil (1996) which show a significant different between gender and service quality

Ho5: Service quality in higher education is the same irrespective to the races.

The finding shows that service quality in higher education would be the same irrespective of races. Therefore whether the students are Chinese, Indians or Malays, the perceptions on service quality are still the same. Based on the finding by Carey et al. (2000), even though there is a differences on the responsibility of the university towards the diverse population, but the other two scales showed no significant difference. So, this mean that if service quality to be measured on overall aspects, the finding may show otherwise.

Ho6: Service quality in higher education is the same irrespective to the semester of studies.

Although in a way, this study tend to agree that students tend to be more critical to their evaluation on service quality as they becoming more experience as suggested by Oldfield and Baron (2000) and how the research by O'Neill (2003) who look upon time factor which influence the rating on service quality by suggesting that the expectation tend to rise which in the end affecting the perceptions of the previous service. Based on the result of this research, it fails to show a significant difference on service quality based on races. 
Ho8: There is no significant relationship between age and service quality in higher education.

The result gave an indication that age does not have any significant relationship with service quality. This is consistent with the finding Ham and Hayduk (2003) that found no relationship between age and service quality.

\subsection{Conclusion}

From the results, it is clear that there are no differences in students' satisfaction towards service quality determinants and overall service quality. The important factors (gender, races and semester of studies and age) that been tested do not have any important role in determining students' satisfaction. Thus, it confirms what other literature try to suggest here, which is by improving service quality, it may potentially improve the students' satisfaction as well and that is the priority of the private higher institutions due to the fact that they have to compete to earn interest from the students to study there.

\subsection{Limitation and Recommendation}

Service quality has been widely accepted as an antecedent of satisfaction and neglecting it may jeopardize the competitiveness of an organization as satisfaction and competitiveness of a service related organizations are inter-related. For that, denying or neglecting the importance of service quality is the same like risking the continuation and the competitiveness of the institutions because by taking it into consideration service quality can actually explain almost $48 \%$ variance in satisfaction. More than that, by focusing on critical factor in service quality especially empathy and assurance mean that the institution is paving a way toward a better evaluation in satisfaction.

(1) One of the limitation in this study is to the context of respondents is very limited to only two private higher institutions that offered bachelor degree courses. As this private higher institutions do offer courses for the diploma and certificate courses, than it should be reasonable that they too are included in the future research.

(2) Further study is suggested to make a comparative study to investigate whether there are any differences in service quality and student satisfaction between public higher institutions and private higher institutions.

(3) Further study should also take serious consideration in terms of accessibility to the data collection because most of the institutions have been very reluctant in giving good cooperation. A serious preparation towards the unexpected situation is needed thus that it is in the ability researcher to face and in control of the situation.

\section{References}

Alridge, S. \& Rowley, J. (2001). Conducting a withdrawal survey. Quality in Higher Education, 7(1), 55-63.

Atheeyaman, A. (1997) Linking student satisfaction and service quality perceptions: the case of university education. European Journal of Marketing, 31(7), 528-540.

Bigne, E., Moliner, M. A. \& Sanchez, J. (2003). Perceived quality and satisfaction in multi service organizations: The case of Spanish public services. The Journal of Services Marketing, 17 (4), 420-442.

Carey, K., Cambiano, R. L. \& De Vore, J. B. (2002). Student to faculty satisfaction

United States. HERDSA, 93-97. Retrieved August

at a Midwestern university in the http://www.ecu.edu.au/conferences/herdsa/main/papers/ref/pdf/ Carey.pdf.

Cheng, Y. T. \& Tam, W. M. (1997). Multi-models of quality in education. Quality Assurance in Education, 5(1), 22-31.

Clewes, D. (2003). A Student-centred Conceptual Model of Service Quality in Higher Education. Quality in Higher Education, 9(1), 69-85.

Corts, D. P., Lounsbury, J. W., Saudargas, R. A. \& Tatum, H. E. (2000). Assessing undergraduate satisfaction with an academic department: a method and case study. College Student Journal. Online: dari World Wide Web: http://www.findarticles.com /cf_0/m0FCR/mag.jhtml on $7^{\text {th }}$ January 2004.

Cronin, J. J. Jr. \& Taylor, S. A. (1992). Measuring service quality: a re-examination and extension. Journal of Marketing, $56,55-68$.

Cuthbert, P. F. (1996). Managing service quality in HE: is SERVQUAL the answer? Part 2. Managing Service Quality, 6(3), 31-35.

Danielson, C. (1998). Is satisfying college students the same as decreasing their dissatisfaction? AIR 1998 Annual Forum Paper. Paper presented at the Annual Forum of the Association for Institutional Research (38th, Minneapolis, MN, May 17-20, 1998), US Michigan.

Elliot, K. M. \& Shin, D. (2002). Student satisfaction: an alternative approach to assessing this important concept. Journal of Higher Education Policy and Management, 24(2), 197-209.

Eimers, M. T. (2001). The Impact of Student Experiences on Progress in College: An Examination of Minority and non minority differences. NASPA Journal, 38(3), 386-409. 
Elrod, R. \& Remirez, R. (July 12, 2002). A Comparison of Institutional Factors \& Student Satisfaction: Retention Implications in a Hispanic Serving Community College. Paper presented at National Community College Hispanic Council 7th Annual Summer Leadership Conference.

Ford, J. B., Joseph, M. \& Joseph, B. (1999). Importance-performance analysis as a strategic tool for service marketers: the case of service quality perceptions of business students in New Zealand and the USA. The Journal of Services Marketing, 13(2), 171-186.

Griemel-Fuhrmann, B. \& Geyer, A. (2003). Students' evaluation of teachers and instructional quality-analysis of relevant factors based on empirical evaluation research. Assessment \& Evaluation in Higher Education, 28 (3), $229-238$. Gronroos, C. (1984). A service quality model and its marketing implications. European Journal of Marketing, 18(4), 36-44.

Ham, L. \& Hayduk, S. (2003). Gaining competitive advantages in higher education: analyzing the gap between expectations and perceptions of service quality. International Journal of Value-Based Management, 16 (3), $223-242$.

Hill, F. M. (1995). Managing service quality in higher education: the role of the student as primary consumer. Quality Assurance in Education, 3(3), 10-21.

Hom, W. (2002). Applying Customer Satisfaction Theory to Community College Planning of of Student Services. IJournal. Retrieved January $7^{\text {th }} 2004$, from http://www.ijournal.us/ issue_02/ij_issue02WillardHom_01.htm.

Iacobucci, D., Ostrom, A. \& Grayson, K. (1995).Distinguishing service quality and customer satisfaction: the voice of the consumer. Journal of Consumer Psychology, 4(3), 277-303.

Joseph, M. \& Joseph, B. (1998). Identifying needs of potential students in tertiary education for strategy development. Quality Assurance in Education, 6(2), 90-96.

Kamal Abouchedid \& Ramzi Nasser (2002). Assuring quality service in higher education: registration and advising attitudes in a private university in Lebanon. Quality Assurance in Education, 10(4), 198-206.

Kanji, G. K., Abdul Malek bin A.Tambi \& Wallace, W. (1999). A comparative study of quality practices in higher education institutions in the US and Malaysia. Total Quality Management, 10(3), 357-371.

Kotler, P. \& Clarke, R. N. (1987). Marketing for health care organizations. Englewood Cliffs, NJ: Prentice-Hall.

Lassar, W. M., Manolis, C. \& Winsor, R. D. (2000). Service quality perspectives and satisfaction in private banking, Journal of Service Marketing, 14 (3), 244-271.

LeBlanc, G. \& Nguyen, N. (1997). Searching for excellence in business education: an exploratory study of customer impressions of service quality. International Journal of Educational Management, 11(2), 72-79.

Ling, C. S. (April 09, 2003). Equal quality education' at private centers. New Strait Time - Management Times.

Mahiah, S., Suhaimi, S. \& Ibrahim., A.(2006). Measuring the level of customer satisfaction among employees of human Resource Division. Advances in Global Business Research 2006. Vol. 3. No.1. ISSN: 1549-9332.

Maushart, J. (December 4, 2003). Study says students are satisfied with college experience. The Daily Aztec, San Diego State U.

Mather, P. (2000). Research, Assessment, and Testing Diversity at ECU: Student Perspectives. Retrieved December $28^{\text {th }}$ 2003 from http://www.ecu.edu.html.

Mohd Feroz Abu Bakar (19 ${ }^{\text {th }}$ October 2004). LAN tolak 40 program IPTS. Berita Harian, 3.

Oldfield, B. M. \& Baron, S. (2000). Students perception of service quality in a UK university business and management faculty. Quality Assurance in Education, 8 (2), 85-95.

O’Neill, M. (2003). The influence of time on student perceptions of service quality: The need for longitudinal measures, Journal of Educational Administration, 41(3), 310-324.

O'Neill, M. A. \& Palmer, A. (2004). Importance-performance analysis: a useful tool for directing continuous quality improvement in higher education. Quality Assurance in Education, 12(1), 39-52.

Palacio, A. B., Meneses, G. D. \& Perez, P. J. P. (2002). The configuration of the university image and its relationship with the satisfaction of students. Journal of Educational Administration, 40(5), 486-505.

Parasuraman, A., Zeithaml, V. A. \& Berry, L. L. (1985). A conceptual model of service quality and its implications for future research. Journal of Marketing, 49, 41-50.

Parasuraman, A., Zeithaml, V. \& Berry, L. (1988). SERVQUAL: a multiple item scale for measuring consumer perceptions of service quality. Journal of Retailing, 6(1), 12-36.

Parasuraman, A., Zeithaml, V. A. \& Berry, L. L. (1990). Five imperatives for improving service quality. Sloan 
Management Review, 29-38.

Parasuraman, A., Zeithaml, V. A. \& Berry, L. L (1996). The behavioral consequences of service quality. Journal of Marketing, 60(2), 31-46.

Perisau S. E. \& McDaniel, J. R. (1996). Assessing service quality in schools of business. International Journal of Quality and Reliability Management, 14(3), 204-218.

Perry, M. J., Sekelsy, M. J. \& Skarsten, F. (March, 2003). University of Michigan-Flint Student Satisfaction Surveys Results. Retrieved January $7^{\text {th }}$, 2004, from http://www.vca.umflint.edu/.

Rajah, D. \& Nadarajah, V. (August 8th, 2000). Go for quality: Musa suggests methods for varsities to improve, New Strait Time, 1.

Renzi, B. M., Allen, M. J., Sarmiento, Y. Q. \& McMillin, J. D. (1993). Alumni perception of the impact of gender on their university experience. Journal of College Student Development, 34, 154-157.

Rowley, J. E. (1996).Customer compatibility management: an alternative perspective on student-to-student support in higher education. International Journal of Educational Management, 10(4), 15-20.

Saaditul Ibrahim, Shamsinar Md SIdin \& Wong Chee Meng (2000). Customer satisfaction towards service quality of higher education in Malaysia. Seminar FEP 2000 Pulau Pinang, 20 - 23 October 2000. Retrieved November $9^{\text {th }}$, 2004, from http://www.econ.upm.edu.my/ repport/mgm11b.html.

Sekaran, U. (1992). Research method for business: A skill building approach. New York: John Wiley \& Sons Inc.

Smith, R. \& Ennew, C. (2001, January). Service quality and its impact on word of mouth communication in higher education. Online: http://www.unim. nottingham.ac.uk/dbm/papers/ 2001-01.pdf. on 15 ${ }^{\text {th }}$ September 2004.

Solomon, M. R. (1996). Consumer behavior. Englewood Cliffs, NJ: Prentice-Hall.

Soutar, G. \& McNeil, M. (1996). measuring service quality in a tertiary institution. Journal of Educational Administration, 34(1), 72-82.

Spencer, R. (1991). After the registration revolution. College and University, 66(4), 209-12.

Spreng, R. A. \& Mackoy, R. D. (1996). An empirical examination of a model of perceived service quality and satisfaction, Journal of Retailing, 72(2), 52-64.

Sweet, J.A. \& Nelson, A. (1997). 1996 UW-Madison undergraduate student satisfaction survey: summary of results. University of Wisconscin Survey Center, University of Wisconsin. Retrieved on August 28 ${ }^{\text {th }}$, 2004, from http://www.ssc.wisc.edu/ sweet/stud96-pt1.html.

Teo, C. L. (October $21^{\text {st }}$ 2001). Realities of private institution. New Strait Time, 4.

Terenzini, P., Rendon, L., Upcraft, L., Millar, S., Allison, K., Gregg, P. \& Jalomo, R. (1996). The transition to college: Diverse students, diverse stories. Research in Higher Research in Higher Education, 35, 57-73.

Umbach, P. D. \& Porter, S. R. (2002). How do academic departments impact student satisfaction? Understanding the contextual effects of departments. Research in Higher Education, 43(2), 209 - 234.

Unprofessional College. (2004, November $\left.1^{\text {st }}\right)$. Harian Metro, 11.

We won't compromise on quality of private higher education, says Hon. (April 02 $\left.{ }^{\text {nd }}, 2001\right)$. New Strait Time, 4.

William, J. (2002). The student satisfaction approach: student feedback and its potential role in quality assessment and enhancement. 24 $4^{\text {th }}$ EAIR Forum, Prague, 8-11 September.

Zammuto, R. F., Keaveney, S. M. \& O'connor, E. J. (1996). Rethinking student services: assessing and improving service quality. Journal of Marketing in Higher Education, 7(1), 45-69.

Zeithaml, V. (1987). Defining and relating price, perceived quality and perceived value. Cambridge, MA: Marketing Science Institute. 
Table 1. Profile of Respondents

\begin{tabular}{|c|c|c|}
\hline Variables & Frequency (n) & Percentage $(\%)$ \\
\hline \multicolumn{3}{|l|}{ Gender } \\
\hline Male & 95 & $47.5 \%$ \\
\hline Female & 105 & $52.5 \%$ \\
\hline \multicolumn{3}{|l|}{ Age } \\
\hline 21 & 40 & $20.0 \%$ \\
\hline 22 & 66 & $33.0 \%$ \\
\hline 23 & 63 & $31.5 \%$ \\
\hline 24 & 20 & $10.0 \%$ \\
\hline 25 & 6 & $3.0 \%$ \\
\hline 26 & 2 & $1.0 \%$ \\
\hline 28 & 2 & $1.0 \%$ \\
\hline 29 & 1 & $0.5 \%$ \\
\hline \multicolumn{3}{|l|}{ Mean age $=22.54$} \\
\hline \multicolumn{3}{|l|}{ Ethnicity } \\
\hline Malay & 144 & $72.0 \%$ \\
\hline Chinese & 25 & $12.5 \%$ \\
\hline Indian & 25 & $12.5 \%$ \\
\hline Others & 6 & $3.0 \%$ \\
\hline \multicolumn{3}{|l|}{ Semester } \\
\hline First Semester & 21 & $10.5 \%$ \\
\hline Second Semester & 40 & $20.0 \%$ \\
\hline Third Semester & 29 & $14.5 \%$ \\
\hline Fourth Semester & 56 & $28.0 \%$ \\
\hline Fifth and Above & 54 & $27.0 \%$ \\
\hline
\end{tabular}

Table 2. T-Test Result

\begin{tabular}{|l|l|l|l|l|l|l|l|}
\hline Gender & N & Mean & $\begin{array}{l}\text { Std. } \\
\text { Deviation }\end{array}$ & $\begin{array}{l}\text { Std. Error } \\
\text { Mean }\end{array}$ & $\mathrm{t}$ & Df & Sig. (2 tailed) \\
\hline Satisfaction & & & & & & & \\
\hline Male & 95 & 4.2561 & 0.99906 & 0.10250 & 1.274 & 198 & 0.204 \\
\hline Female & 105 & 4.0873 & 0.87556 & 0.08545 & 1.265 & 187.986 & 0.207 \\
\hline Total & 200 & & & & & & \\
\hline Service Quality & & & & & & & 1.489 \\
\hline Male & 95 & 4.1491 & 0.72790 & 0.07468 & 198 & 0.138 \\
\hline Female & 105 & 4.0041 & 0.64836 & 0.06327 & 1.481 & 189.249 & 0.140 \\
\hline Total & 200 & & & & & & \\
\hline
\end{tabular}


Table 3. ANOVA Results

\begin{tabular}{|c|c|c|c|c|}
\hline Variables & Mean & Std. Deviation & $\mathbf{F}$ & Sig. $\mathrm{F}$ \\
\hline \multicolumn{5}{|l|}{ Student Satisfaction } \\
\hline \multicolumn{5}{|l|}{ Races } \\
\hline Malay & 4.1412 & 0.81800 & 1.453 & 0.229 \\
\hline Chinese & 4.1000 & 1.33420 & & \\
\hline Indian & 4.4867 & 1.07467 & & \\
\hline Others & 3.7500 & 1.00416 & & \\
\hline \multicolumn{5}{|l|}{ Semester } \\
\hline First Semester & 4.2698 & 1.20240 & 0.332 & 0.856 \\
\hline Second Semester & 4.2583 & 1.06079 & & \\
\hline Third Semester & 4.2184 & 1.06263 & & \\
\hline Fourth Semester & 4.1280 & 0.83242 & & \\
\hline Fifth Semester and above & 4.0741 & 0.76798 & & \\
\hline \multicolumn{5}{|l|}{ Service Quality } \\
\hline \multicolumn{5}{|l|}{ Races } \\
\hline Malay & 4.0346 & 0.62168 & 0.972 & 0.407 \\
\hline Chinese & 4.1213 & 0.87313 & & \\
\hline Indian & 4.2754 & 0.84909 & & \\
\hline Others & 3.9493 & 0.68105 & & \\
\hline \multicolumn{5}{|l|}{ Semester } \\
\hline First Semester & 4.0590 & 0.70225 & 0.722 & 0.578 \\
\hline Second Semester & 4.1784 & 0.72205 & & \\
\hline Third Semester & 4.1938 & 0.68278 & & \\
\hline Fourth Semester & 4.0137 & 0.78322 & & \\
\hline Fifth Semester and above & 3.9969 & 0.55291 & & \\
\hline
\end{tabular}

Table 4. Correlation Results

\begin{tabular}{|l|l|l|l|l|l|l|l|}
\hline Variable Type & $\mathrm{Y}$ & $\mathrm{X} 1$ & $\mathrm{X} 2$ & $\mathrm{X} 3$ & $\mathrm{X} 4$ & $\mathrm{X} 5$ & $\mathrm{X} 6$ \\
\hline $\begin{array}{l}\text { Dependent } \\
\mathrm{Y}=\text { Satisfaction }\end{array}$ & 1.00 & & & & & \\
\hline $\begin{array}{l}\text { Independent } \\
\mathrm{X} 1=\text { Age }\end{array}$ & 0.09 & 1.00 & & & & & \\
\hline $\mathrm{X} 2=$ Tangibility & $0.568^{* *}$ & -0.27 & 1.00 & & & & \\
\hline $\mathrm{X} 3=$ Assurance & $0.582^{* *}$ & -0.018 & $0.699^{* *}$ & 1.00 & & & \\
\hline $\mathrm{X} 4=$ Reliability & $0.555^{* *}$ & -0.031 & $0.728^{* *}$ & $0.789^{* *}$ & 1.00 & & \\
\hline $\mathrm{X} 5=$ Responsiveness & $0.556^{* *}$ & -0.026 & $0.669 * *$ & $0.776^{* *}$ & $0.847^{* *}$ & 1.00 & \\
\hline $\mathrm{X} 6=$ Empathy & $0.640^{* *}$ & -0.037 & $0.688^{* *}$ & $0.623^{* *}$ & $0.763^{* *}$ & $0.747^{* *}$ & 1.00 \\
\hline $\mathrm{X} 7=$ Service Quality & $0.653^{* *}$ & -0.031 & $0.899^{* *}$ & $0.867^{* *}$ & $0.914^{* *}$ & $0.885^{* *}$ & $0.849^{* *}$ \\
\hline$*$ Correlation is significant at the 0.05 level (2-tailed) & & & \\
\hline$*$ Correlation is significant at the 0.01 level (2-tailed) & & & \\
\hline
\end{tabular}




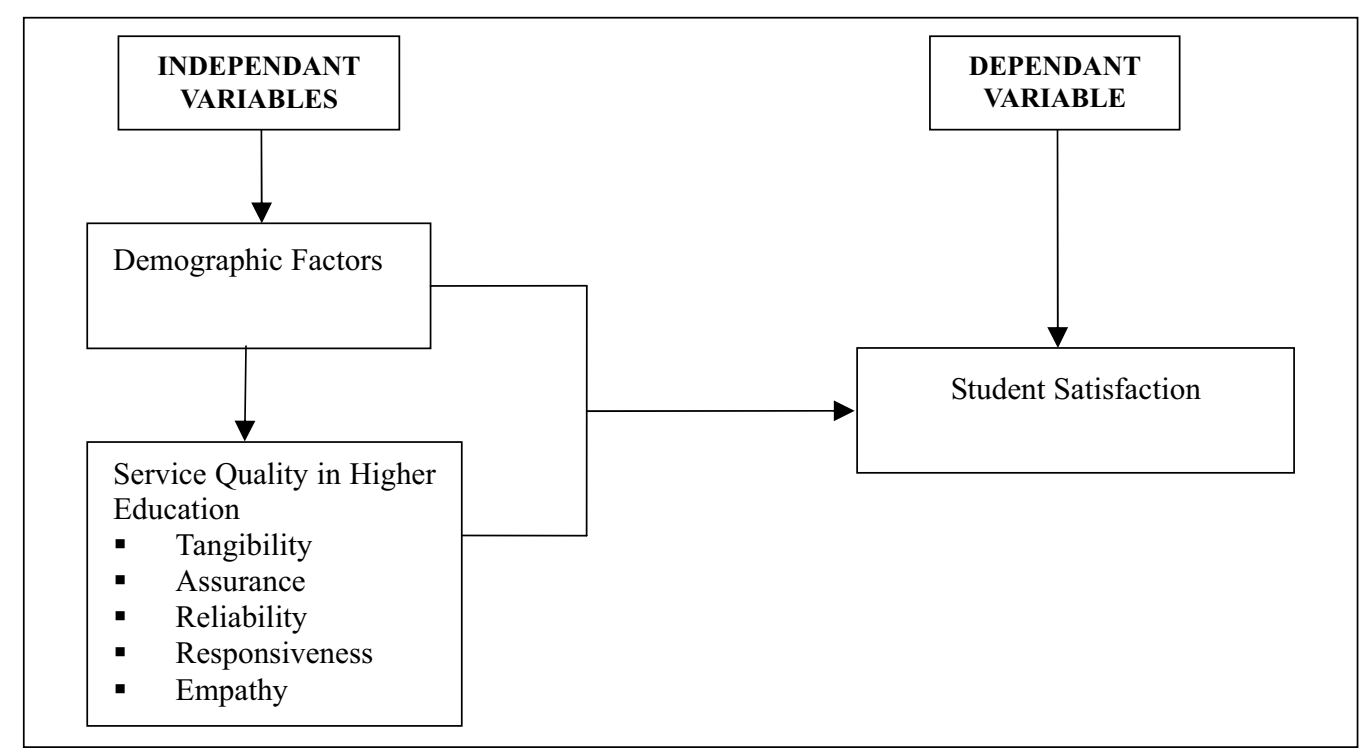

Figure 1. Research Framework 